\title{
The Effect of Tri Hita Karana Oriented Blended Learning Model on Students Character and Learning Outcomes at the Faculty of Education, Undiksha
}

\author{
Ignatius I Wayan Suwatra ${ }^{*}$, Anak Agung Gede Agung ${ }^{1}$, I Made Tegeh ${ }^{1}$, Luh Putu \\ Putrini Mahadewi ${ }^{1}$
}

${ }^{1}$ Universitas Pendidikan Ganesha, Indonesia
${ }^{*}$ Corresponding author. Email: ignatiusiwayan.suwatra@undiksha.ac.id

\begin{abstract}
This study adapts the blended learning model. This model was chosen to overcome the weaknesses that occur in conventional learning activities. This study examines the effect of Tri Hita Karana-oriented Blended Learning in improving the character and learning outcomes of students at the Faculty of Education, Undiksha. The research aims to determine the differences in character and learning outcomes between students who learn using the Tri Hita Karana oriented blended learning model with the Direct instruction learning model. This research is a quantitative research with a quasi-experimental approach. The research design was a posttest only control group design. The population in this study were all students of the Faculty of Education which about 1719 people. The research sample was determined by using purposive sampling technique. The instruments used were character observation sheets and learning outcomes tests. Data were analyzed using descriptive statistics and inferential t-test statistics. The results showed that there were 2 subjects that had significant differences in learning outcomes between the experimental class and the control class, namely (1) Introduction to Educational Technology and (2) Descriptive Statistics. Two other subjects, namely (1) Student Development and (2) Early Childhood Mathematics Education, shows that there is no significant difference in learning outcomes between the experimental class and the control class. In the character variable, there were significant differences in the character of students in the Introduction to Educational Technology and Descriptive Statistics courses, while in the Student Development and Early Childhood Mathematics Education courses there was no significant difference.
\end{abstract}

\section{Keywords: Blended Learning, Tri Black Katana, Character, Learning Outcomes}

\section{INTRODUCTION}

The influence of information and communication technology (ICT) in the world of education is increasingly felt in line with the shift in learning patterns from conventional face-to-face learning towards more open learning and using Mukhoadhyay media [1]. In this era of information technology, learning activities are no longer limited by building walls. ICT has opened wide access to be able to participate in more flexible learning activities. It also opens opportunities for students to take part in the same learning at other campuses through online-based distance learning. The internet is no stranger to students. The results of the study note that internet users in Indonesia who come from among children and adolescents are predicted to reach 30 million. As many as 98 percent of children and adolescents claim to know about the internet and 79.5 percent of them are internet users [2]. The results of this study indicate that the internet is needed by all people and is a great opportunity to be used to improve the quality of education, including learning in higher education. Given that the internet is very familiar among teenagers, the internet is used for learning as well as entertainment media. However, especially in tertiary institutions, apart from not using the internet optimally, learning is still predominantly conventional, in the form of face-to-face activities. There are several drawbacks to face-to-face learning. First, the time to study face-to-face in college is limited. Second, learning tends to be uniform and simultaneous. Third, learning is less flexible. Fourth, in face-to-face learning, educators or lecturers cannot fully 
attend. Fifth, the control of learning is entirely with the lecturer. To anticipate the use of the internet that is not appropriate and lacks in face-to-face learning, it is necessary to test e-learning portals and blended learning strategies that combine face-to-face learning and online learning in improving student character and learning outcomes. The blended learning model tested in it creates innovative content and innovative task plans (RTM). This model provides opportunities for students to access assignments and learning materials according to their respective learning speeds anytime and anywhere. Several research results indicate that the blended learning model has a positive impact. The results of the study [3] show that blended learning has a positive impact on students. Blended learning settings are able to improve student learning achievement both in quantity and quality. Students also show a positive attitude towards the application of blended learning. Taking into account the results of this study, testing the Tri Hita Karana based blended learning model at the Undiksha Faculty of Education is a solution that is expected to solve problems, such as: 1) limited face-to-face learning time between lecturers and students, 2) limited student learning freedom according to ability respectively, which have tended to be simultaneous and uniform, 3) the inadequate use of ICT (internet) among lecturers and students for learning, and 4) not yet realizing an ICT-based learning climate.

\section{METHOD}

This research is an experimental research (quasiexperimental / quasi-experimental). The population of this study were students at the Undiksha Faculty of Education. The research sample was determined using a purposive sampling technique by selecting classes that have the eligibility to be the research sample. The experimental design or design used is as follows.

Table 1. Posttest Only Control Group Design Experiment Design

\begin{tabular}{|c|c|c|c|}
\hline $\mathrm{E}$ & $:$ & $\mathrm{X}$ & $\mathrm{O} 1$ \\
\hline $\mathrm{K}$ & $:$ & - & $\mathrm{O} 2$ \\
\hline
\end{tabular}

Research Data Analysis Design. The data in this study were analyzed using multi-variate analysis of variance analysis (Manova) or multi-variance analysis of variance.

Table 2. Research Design with One Way Manova

\begin{tabular}{|c|c|}
\hline \multicolumn{2}{|c|}{ A } \\
\hline $\mathbf{A 1}$ & $\mathbf{A 2}$ \\
\hline $\mathrm{X}_{1}$ & $\mathrm{X}_{2}$ \\
\hline $\mathrm{Y}_{1}$ & $\mathrm{Y}_{2}$ \\
\hline
\end{tabular}

A = Learning Model;

$\mathrm{X}=$ Learning Outcomes;

$\mathrm{Y}=$ Character

A1 = Blended Learning Model
$\mathrm{X} 1$ = learning outcomes using the blended learning model

Y1 $=$ Character using the blended learning model

A2 $=$ Direct Instruction Model

$\mathrm{X} 2$ = learning outcomes with direct instruction model

$\mathrm{Y} 2=$ Character with direct instruction model

This study involved the dependent variable character and learning outcomes, and independent variables, namely the blended learning model and the Direct Instruction model.

Data Collection Methods and Instruments. The data in this study were collected using observation sheets (to collect data on student character development), questionnaires to measure the validity of learning devices, and learning outcomes tests to determine the effect of the Tri Hita Karana based blended learning model.

Data analysis technique. Data about the validity of the device were analyzed descriptively, namely by using the frequency distribution technique. Data about student character were analyzed qualitatively and quantitatively. Student learning outcomes data were analyzed using inferential statistical techniques. Before testing the hypothesis, a prerequisite test is conducted which includes: normality test and homogeneity test. The prerequisite test was carried out with the help of SPSS software.

\section{RESULTS AND DISCUSSION RESULTS}

This research was conducted for two months with 8 face-to-face meetings combined with online learning. The following is an example of the appearance of elearning for 6 online courses

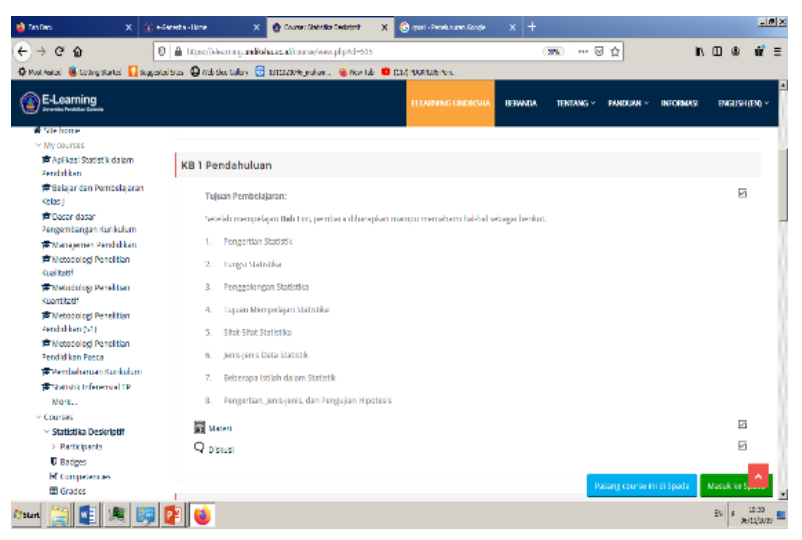

Figure 1 E-learning Descriptive Statistics Course

Prior to the experiment, the instrument validity test was conducted in the form of a multiple choice test. The validity of the test content is assessed by two experts who are competent in their field. The coefficient of the content validity of the descriptive statistics course instrument reaches 1.00 , the coefficient of content validity in the 
Development of participants course is 0.98, the introductory course has a validity coefficient of 1.00 , the mathematics course AUD the validity coefficient is 0.97 . So this instrument is worth using.

The results of hypothesis testing in the Mathematics AUD course showed that the significance value of the learning outcomes and character variables was 0.961 (insignificant) and 0.465 (insignificant). In the Introductory TP course, the significant value of the learning outcomes and character variables reaches 0.000 (Significant) and 0.000 (Significant). In the Descriptive Statistics course, the significant values of the learning outcomes and character variables reached 0.003 (Significant) and 0.000 (Significant). In the Student Development course, the significant values of the learning outcomes and character variables reached 0.105 (insignificant) and 0.063 (insignificant).

\section{DISCUSSION}

In the Introductory $\mathrm{TP}$ and Descriptive Statistics courses, it was found that there were significant differences in learning outcomes between students who studied in the blended learning model and the direct instruction model. There are several factors that are thought to influence student learning outcomes to be better than student learning outcomes in the control class.

1. Students in the experimental class can learn more flexibly and systematically. Electronic learning (elearning) provides facilities for students to be able to access material anytime and anywhere without depending on face-to-face meetings. Students can access digital material and do not have to rely on printed material. Besides being flexible, the student learning process is also more systematic. In e-learning, each chapter or topic contains tasks that are presented online and contains the timeframe for making assignments. The existence of this time span triggers student learning motivation to be higher. The findings of this study are supported by Claude, Muellerl, Alde, Müller, \& Maximilian (2018) research conducted byshowing that blended learning allows learners to be more flexible in learning, especially freedom in terms of: study time, place of study, speed, learning style, freedom to choose content, assessment and learning flow [4].

2. Students get feedback (feedback) quickly. Students can more easily understand learning material because in e-learning students are facilitated with a discussion feature so that lecturers and peers can provide feedback on answers uploaded by students. Feedback given by lecturers and peers will encourage students to improve the quality of assignments on the next topic.

3. Students in the experimental class are more motivated. The motivation given is more of an external motivation through the assignment of tasks which are strictly regulated by the system. Students who are late in discussing and uploading assignments to the system will not get a score. This is thought to make students motivated to do tasks on the e-learning system. The results showed that students who were disciplined in sending assignments tended to have better learning outcomes. The findings of this study are in line with the findings of research conducted by Sjukur [5]. That blended learning can increase learning motivation. Sucaromana's research results also show that students who learn through blended learning have higher intrinsic motivation than students who learn face-toface [6].

4. The opportunity for learning interaction is higher. In the Experiment class, students learn face-to-face and online. This merger provides more opportunities for student-lecturer interaction so that the learning process tends to be more effective. When students are reluctant to ask face-to-face questions, they can submit questions online in the discussion feature. This activity will help improve student understanding of the course material being studied. The results of this study are in line with the findings of Bates (1955); Wulf (1996) in [1]. That blended learning increases the level of learning interaction between students and teachers or instructors.

The occurrence of significant differences in student character between the experimental class and the control class is caused by the following reasons [7].

1. E-learning applies a time system to form a disciplined attitude. In e-learning students are given assignments that they have to do at a predetermined time. This predefined time span requires students to be disciplined in the use of time. Because if they are not disciplined with time, then they will be left behind or lose time which is impossible to catch up, because the system will be closed automatically and students who are late in uploading assignments will not be served by the system.

2. The e-learning system provides discussion features to develop social attitudes. The discussion feature will be a stimulus for students to develop social attitudes, in addition to increasing understanding. The use of the discussion feature refers to the social learning theory which states that students will find it easier to learn with social interactions. To facilitate this interaction, e-learning provides a discussion forum.

3. In blended learning, it appears that students have a cooperative, caring and responsible attitude towards the environment and facilities, are confident, have tolerant behavior, and respect the opinions of others, which are good. All of these characters are the important foundations of 21 st century human skills. These findings are consistent with Marsh's (2012) 
explanation that blended learning helps students develop valuable skills needed in the 21 st century [8].

4. In face-to-face classroom learning, students are given practice assignments in Chapters I to VIII. The practice assignments are written in a ledger (double folio striped book) and must be handwritten. The task aims to shape the character of students in the following matters.

a. Read more diligently, because the assignment cannot be postponed,

b. Work more systematically in doing assignments, because by thinking and working systematically, students can do assignments well,

c. Work neatly, because this neat attitude and behavior shows a person's personality or character.

d. Practicing good and correct writing skills, because good and correct writing can give a positive impression about one's self-image,

e. Train students' memory, because doing regular / frequent practice assignments will improve one's memory and understanding.

In this study there are two subjects which show that there is no significant difference in learning outcomes and character in the experimental class and the control class, namely the AUD Mathematics course and Student Development, although theoretically it is believed that blended learning can provide better learning outcomes. than traditional learning such as the direct instruction model. There are several possible causes.

1. Weaknesses in the aspect of research procedures. At the beginning of the lesson each class is given printed material in the form of the same module, complete with a summary of the material at the end of the chapter and practice questions that must be done by students. The difference is, in the class that is taught using the blended learning model, an additional assignment is given at the end of the module which is presented on-line and discussed on-line as well. In the control class, learning is carried out using a class discussion model with the material according to the module content

2. Weaknesses of the instrument (measuring instrument), which were tested only by using the content validity. Ideally, the measuring instrument in the form of a test of learning outcomes is tested as a whole for validity, reliability and the level of difficulty of the items. However, this was not fully fulfilled in the preparation of this instrument.

3. Internal ability of research subjects. It is statistically proven that both the experimental group and the control group are homogeneous. The ability of students in the experimental group and the control group is relatively the same statistically. However, the internal conditions of research subjects (students) largely determine the quality of their learning processes and outcomes. This can be seen from the scores of learning outcomes in the experimental group and the control group. There was a very wide variance of scores with the highest score and the lowest score classified as extreme. In addition, external conditions such as the condition of the classroom, Wi-Fi, the psychological atmosphere while taking the test and so on, can also contribute to this condition.

4. Small number of samples. The research sample was 25 people in the experimental group and 22 people in the control group. The small number of samples is not due to reduction but the number of students (research subjects) in the class / group is indeed the case.

5. Students' readiness in participating in the blended learning model. Although it has been recognized by the wider community that blended learning is a very adequate choice today, not all strata of the student community have been able to follow learning using this model properly, including what happened to the subject of this study. In many cases, students are more ready to learn face-to-face model.

6. Inadequate internet network. In the application of the e-learning program, students are still constrained by a limited internet network. This results in e-learning access which is rarely done by students.

7. Limited time working on questions. The time given to work on the questions is one minute per question. Sometimes it takes a long time to load to access the next question resulting in inadequate time given. As a result, students are not able to look at the questions properly and tend to answer randomly, so the scores obtained are not as expected.

Although theoretically it is considered that the use of blended learning in learning strongly supports the improvement of the learning process and outcomes, but in curricular terms, the reality in the field is still very possible for an insignificant difference in learning outcomes between learning using the blended learning model and face-to-face learning models. Not all learning materials according to the curriculum bill are suitable for using the blended learning model. "E-learning is not always appropriate to be implemented in all curricula. Some curricula are appropriate to be learned by traditional learning, but some curricula are appropriate to be learned by e-learning, depending on the purposes of each curriculum" [9].

Furthermore, a study conducted in grade 11 on electrical engineering and talking the electrical machinery at the Advanced Vocational School in Taiwan also found that there was no significant difference between the learning outcomes test with blended learning and traditional learning. There were no significant 
differences in achievement test score between blended learning and traditional learning [10]

This is also an indication that there is a part of the module material used in learning with a blended learning model that is more appropriately presented through traditional learning. Therefore, before treatment, it is necessary to carry out an adequate study of the feasibility of the module material to be presented with a blended learning model.

The results of this study also indicate that there is no difference in character between groups of students who learn using the blended learning model and groups of students who learn using the direct instruction model.

Character measurement is done by using an observation sheet. The character component is measured using 18 items. In the control group, observations were made during each lesson, while in the experimental group the observations were made during the pre-test and posttest. The results of data analysis showed that there was no significant difference in the character of students in the experimental group and in the control group. This is very possible because, Undiksha carries the Tri Hita Karana (THK) philosophy which must be implemented in everyday life, on campus and off campus. In fact, the character values are already included in the THK. Since the 2019-2020 academic year all Undiksha first semester students receive THK courses and it is mandatory for all students to participate as characteristics and breath of Undiksha's life which emphasizes harmony in campus life.

\section{CONCLUSION}

The conclusions that can be drawn from the research are:

1) There is a significant difference in student character between groups of students who study using the blended learning model and groups of students who study using the direct instruction model in the Descriptive Statistics and Educational Technology courses, but there is no significant difference in the character of students between groups of students studying using a blended learning model and groups of students who learn using the direct instruction model in the AUD Mathematics course and Student Development.

2 There is a significant difference in learning outcomes between groups of students who study using the blended learning model and groups of students who study using the direct instruction model in Descriptive Statistics and Introduction to Educational Technology courses, but there is no significant difference in learning outcomes between groups of students learning using the model blended learning and student groups who learn using the direct instruction model in the AUD Mathematics course and Student Development.

\section{REFERENCES}

[1] E. Usman, D. Kuriniawan and C. Riayana, Pembelajaran Berbasis Teknologi Informasi dan Komunikasi: Mengembangkan Profesionalisme Guru, Jakarta: PT Rajagrafindo Persada, 2011.

[2] Tekno kompas, Hasil Survei Pemakaian Internet Remaja Indonesia., 29 Juni 2014, [Online]. Available: http://tekno.kompas.com.

[3] Dwaik, Raghad, A. Jweiless and S. Shrouf, Using Blended Learning to Enhance Student Learning in American Literature Courses, The Turkish Online Journal of Educational Technology, vol. 15(2), 2016, pp. 126-137.

[4] Claude, S. Muellerl, M. Alde, M. Müller and Maximilian, Learning Effectiveness and Students' Perceptions in A Flexible Learning Course," European Journal of Open, Distance and ELearning, vol 21, 2018, pp. 44-52. 10.2478/eurodl2018-0006.

[5] S. B. Sjukur, Pengaruh Blended Learning Terhada Motivasi Belajar, in: Jurnal Pendidikan Vokasi, 2012, pp. 368-378.

[6] U. Sucaromana, The Effects of Blended Learning on the Intrinsic Motivation of Thai, English Language Teaching, 2018, pp. 141-147.

[7] N. Alsalhi, M. Eltahir and S. Al-Qatawneh, The Effect of Blended Learning on Achievement of Ninth Grade Students in Science and Their Attitudes Towards Its Use, Science Direct, 2019.

[8] D. Marsh, Blended Learning: Creating Learning Opportunities for Language Learners, New York, USA: Cambridge University Press, 2012.

[9] D. U. Bolliger and T. \& Martindale, Key Factors For Determining Student Satisfaction In Online Courses, in: International Journal on E-Learning, Vol. 3(1), 2004, pp. 61-67.

[10] C.-C. Chang, K.-M. Shu, C. Liang, J.-S. Tseng and Y.-S. Hsu, Is Blended e-Learning as Measured by an Achievement Test and Self-Assessment Better than Traditional Classroom Learning for Vocational High School Students?, in: International Review of Research in Open and Distance Learning, vol. 15(2), 2014, pp. 213-231.

[11] J. M. Gee, Learning by design: Good video games as learning machines, E-Learning, vol. 2(1), 2005 pp. 5-16. 